\title{
Coral disease in Micronesian reefs: a link between disease prevalence and host abundance
}

\author{
Roxanna L. Myers ${ }^{1}$, Laurie J. Raymundo ${ }^{1,2, *}$ \\ ${ }^{1}$ University of Guam Marine Laboratory, UOG Station, Mangilao, Guam 96923 \\ ${ }^{2}$ Division of Ecology and Evolutionary Biology, Cornell University, Ithaca, New York 14850, USA
}

\begin{abstract}
Current information regarding the effects of coral diseases on Indo-Pacific reefs lags behind that of the Caribbean. Considering that these reefs are geographically widespread, speciose, often highly influenced by human coastal populations, and inadequately monitored, developing a baseline database is a primary management issue for local scientists. In a first attempt to quantify diseases in Micronesia, Guam reefs were assessed for disease prevalence, host abundance, and community structure. Surveys of 15 reefs revealed 6 disease states affecting 8 families of reef-building corals and highly variable prevalence between sites, ranging from 0.2 to $12.6 \%$. Guam reefs are taxonomically diverse but dominated by the genus Porites. Coral generic host abundance showed a significant and positive link with total disease prevalence. Five out of 6 of the observed disease states affected Porites spp. (mean prevalence within the genus: $6.14 \pm 0.88 \%$ ), and acroporids and pocilloporids also showed high susceptibility. As the coral genera currently most affected by diseases are those providing the most structure to Guam's reefs, disease has the potential to have significant longterm effects, highlighting an urgent need for proactive management.
\end{abstract}

KEY WORDS: Coral disease $\cdot$ Porites $\cdot$ Host abundance $\cdot$ Guam

\section{INTRODUCTION}

Infectious disease is a natural component of all communities, and virulence, transmission rate, and geographic and host range can vary both temporally and spatially, thus influencing the effect of a disease. Changes in these attributes can affect the persistence of vulnerable species and, therefore, ecosystems as a whole. In recent years, reports of diseases affecting corals have increased (Porter et al. 2001, Green \& Bruckner 2000, Sutherland et al. 2004, Weil 2004, Raymundo et al. 2005). Poor water quality from anthropogenic inputs to nearshore reefs, overfishing, and global climate change may all be implicated in these increases (Harvell et al. 1999, 2007), although rigorous data are lacking from many of the world's coral reef areas. Despite the lack of baseline information from many regions, existing data point to disease as a growing problem on reefs worldwide, requiring urgent management. In the Caribbean, infectious disease has been implicated in the rapid and severe decline in coral cover and drastic community changes (Hughes 1994, Aronson \& Precht 2001, Porter et al. 2001, Sutherland et al. 2004).

In contrast, disease effects in the Indo-Pacific region, which is geographically more extensive and speciose, are poorly documented. This region contains a plethora of scattered, remote islands, as well as large island chains with huge coastal populations that have had devastating effects on reef health in many areas (Gomez 1988, Hughes et al. 2003). Until recently, it was tacitly assumed that diseases are less prevalent and severe in this region. However, recent limited evidence from the few sites where disease has been studied (Willis et al. 2004, Raymundo et al. 2005, Aeby 2006) suggests that it can be a major factor in coral loss in certain areas, while other areas remain relatively unaffected. With the global center of reef biodiversity 
located in this region, filling in this knowledge gap is of utmost importance.

Coral disease has been unexamined in the central Pacific until recently. On the island of Guam $\left(13^{\circ} 28^{\prime} \mathrm{N}, 144^{\circ} 47^{\prime} \mathrm{E}\right)$, Cheney (1975) provided the first physical description of coral tumors affecting the genus Acropora, but virtually no progress has been made since that initial effort. With the increasing awareness of the impacts disease is having on coral reefs world-wide, quantifying the current status of diseases present on Guam reefs was considered a management priority for local scientists (Porter et al. 2005). In addition, Guam reefs are currently exposed to a multitude of anthropogenic effects while simultaneously serving as an important economic resource via tourism. The proposed expansion of the military presence in Guam is expected to increase the population by at least 20000 over the next 5 yr, and managers are deeply concerned over the impacts this increase will have on nearshore ecosystems. In light of this, the aim of this study was to quantify (1) benthic composition within reef communities (2) coral disease prevalence; and (3) sources and prevalence of other signs of compromised health affecting corals on these reefs. These data have served to establish a

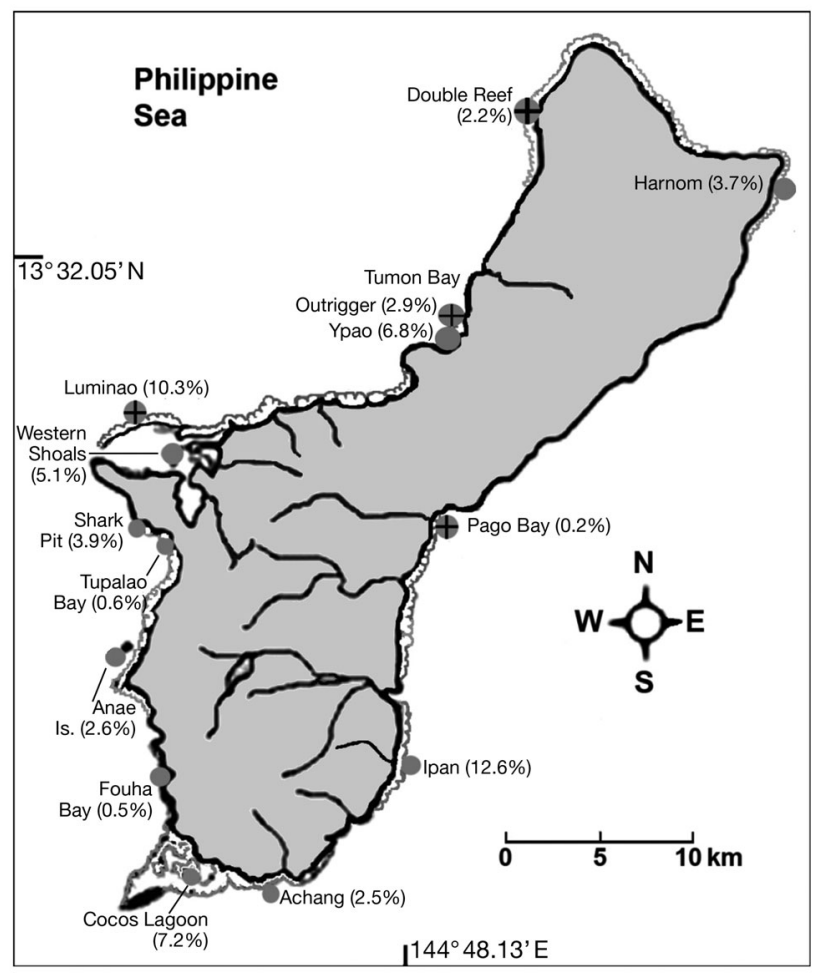

Fig. 1. Guam, showing survey sites (grey dots) and long-term monitoring sites (grey dots with crosses). Numbers in parentheses indicate mean total disease prevalence for each site ( $\mathrm{n}=3$ transects site ${ }^{-1}$ ) baseline view of the status of Guam reefs for future reference, identify issues for targeted research and management efforts, and locate areas for long-term monitoring.

\section{MATERIALS AND METHODS}

To establish a baseline disease prevalence level and assess the degree of variability in prevalence between sites around Guam, sites were chosen based on a variety of factors that included Marine Protected Area (MPA) status, popularity as a tourist dive destination, reported disease outbreaks, suspected elevated nutrient and/or sediment load, and variability in coral abundance. To date, 15 reefs have been surveyed for benthic composition, coral generic richness, coral disease prevalence, bleaching, predation, and other signs of compromised health such as competitive overgrowths and physical damage (Fig. 1). Field assessment of disease signs and compromised health states followed descriptions in Raymundo et al. (2008). Although coral cover varied considerably between reefs, surveys were generally concentrated in areas of highest coral cover at each site, either the reef flat or nearshore reef slope, so as to maximize the size of the coral population sampled.

Sites were surveyed using three $20 \times 2 \mathrm{~m}$ belt transects at each location, generally laid parallel to the shoreline, spaced 10 to $20 \mathrm{~m}$ apart. Multiple randomized rarefaction curves were plotted per site to verify that this sample area $\left(120 \mathrm{~m}^{2}\right)$ was sufficient to quantify hard coral generic diversity within our sites. Surveyed depths ranged from 1 to $12 \mathrm{~m}$, depending on the degree of slope. Each transect was read using the Line Intercept method (English et al. 1997) to characterize benthic composition, and all coral colonies were counted and identified to genus within the $2 \mathrm{~m}$ belt. Colonies on the belt margin were counted only when $50 \%$ or more of the colony lay within the belt. Assessments were made underwater using a Bausch \& Lomb magnifying lens, except for rare cases when verification required sampling a small portion of the tissue and skeleton to be examined in the laboratory under a dissecting microscope. For consistency in field diagnoses between 2 observers, field assessment of disease and compromised health signs were discussed prior to initiating surveys, and photo documentation during surveys provided additional information if diagnoses were questionable.

Disease prevalence, generic abundance, and benthic composition data were tested to meet the assumptions of normality (Kolmogorov's test) and homoscedasticity (Levene's test) in DataDesk 6.0 (Velleman 1988). For these data, a 1-way analysis of variance (ANOVA) was 
used to compare disease prevalence, generic abundance, and live coral cover between sites. Linear regression was used to examine a relationship between the abundance of coral host genera and disease prevalence. A step-wise multiple regression was used to test for drivers of variability in total disease prevalence between sites. Factors tested were colony abundance of the 3 most common genera (Porites, Acropora, Pocillopora), transect depth, proximity to a river mouth (as a proxy for total anthropogenic inputs), geographic position on the island (i.e. north versus south coast and east versus west coast, reflecting the position of rivers and seasonal wave and wind influences; Fig. 1), and mean percent live hard coral cover.

\section{RESULTS}

\section{Coral disease}

Six disease states were documented from the 15 surveyed sites (Fig. 2): (1) white syndrome, (2) ulcerative white spot disease, (3) black band disease, (4) brown band disease, (5) skeletal eroding band (SEB), and (6) growth anomalies. Coral disease was found at all sites surveyed and varied significantly between sites, ranging from a high of $12.6 \pm 1.5 \%$ to a low of $0.2 \pm 0.03 \%$ (1-way ANOVA: $F_{\mathrm{s}}=3.731, \mathrm{p}<0.01$, df $=42$; Fig. 1). Two sites (Ipan and Luminao reef flats) exhibited disease prevalence $>10 \%$, while 3 sites (Pago, Tupalao, and Fouha Bays) showed prevalence $<1 \%$.

Disease also affected families differentially; Porites showed both the highest abundance and total disease prevalence, while faviids and acroporids were similarly abundant, although disease prevalence was much higher among acroporids (Fig. 3). Pocilloporids and agariciids (Pavona spp.) comprised roughly $7 \%$ and $4 \%$, respectively, of most coral communities, but diseases affected pocilloporids more frequently than agariciids (Fig. 3). However, overall, disease prevalence correlated strongly and positively with taxon abundance $\left(\mathrm{R}^{2}=0.689 ; \mathrm{p}=0.0001\right.$; Fig. 4). Further, the combined abundance of Poritidae, Pocilloporidae, and Acroporidae explained $36 \%$ of the variation in disease prevalence between sites $\left(\mathrm{R}_{\text {adj }}^{2}=0.363\right.$; acroporid abundance: $\mathrm{p}=0.02$; pocilloporid abundance: $\mathrm{p}=0.01$; poritid abundance: $p=0.12$ ). None of the other factors we tested in our multiple regression improved the overall fit of the model. This suggests that there are other factors that we were unable to address in our baseline surveys that contributed to the variation in between-site disease prevalence.

White syndrome was the most prevalent disease (8.9\% mean prevalence; range 0 to $26.3 \%$ ), was found on 14 out of 15 of the reefs surveyed, and affected 8 genera from 5 families (Fig. 3). Ulcerative white spots were found only on the genus Porites on Guam, but was the second most prevalent disease $(2.8 \%$ mean prevalence; range: 0 to $17.4 \%$ ) and was also found on 14 out of 15 surveyed reefs. Brown band disease affected only thicket-forming Acropora in the 2 reefs with high Acropora spp. abundance (Tumon Bay and Luminao reef; mean prevalence: $1.0 \%$; range: 0 to $9.1 \%$ ). SEB occurred primarily in diffuse patches of bare skeleton, rather than in a discrete band, and was often found as a secondary infection on white syndrome-affected patches or on predation scars. This disease was highly prevalent at only 1 site, Shark Pit, where it affected numerous Millepora colonies that were also displaying signs of white syndrome (SEB prevalence on this reef: $11.3 \%$, representing the highest value; mean prevalence: $1.2 \%$ ). Black band disease was the rarest of those recorded $(0.2 \%$ mean prevalence; range 0 to $2.7 \%$ ) and was limited to 3 reefs. Subsequent observations on monitored sites indicate that it is normally rare, affecting only 1 or 2 colonies of a single species per reef (L. Raymundo pers. obs). However, at Harnom (prevalence: $2.7 \%$ ), black band was observed on numerous encrusting Montipora colonies. At Luminao, the disease is common on Goniopora fruticosa during the warm season (mean temperature: 30 to $32^{\circ} \mathrm{C}$ i February to August) and is rare to absent during the cooler months (mean temperature: 27 to $29^{\circ} \mathrm{C}$; September to January; L. Raymundo unpubl. data).

\section{Benthic community structure and sources of compromised health}

Surveyed sites included lagoon areas, reef flats, patch reefs, reef crests, and fore-reefs. As Guam lies within the typhoon belt, benthic topographic relief was low at most sites, coral species assemblages did not include finely branching or foliose morphologies, and substrates were dominated by pavement with turf algae, reflecting an influence of high wave energy (Fig. 5). The amount of live coral varied significantly by site, with Western Shoals reef crest having the highest percent cover $(72.5 \pm 4.0 \%)$ and the Achang MPA reef flat with the lowest $(3.5 \pm 0.2 \%$; 1-way ANOVA: $F_{\mathrm{s}}=16.6316, \mathrm{p}<0.001, \mathrm{df}=41$; Fig. 5). The coral communities were represented by 12 major families, dominated by Poritidae (49.8\% of total live coral cover), Acroporidae (18.0\%), and Faviidae (14.9\%). All other families generally composed a small fraction of coral cover.

Other site-specific conditions influencing coral health included overgrowth by the coral-killing sponge Terpios sp. (Plucer-Rosario 1987), predation 

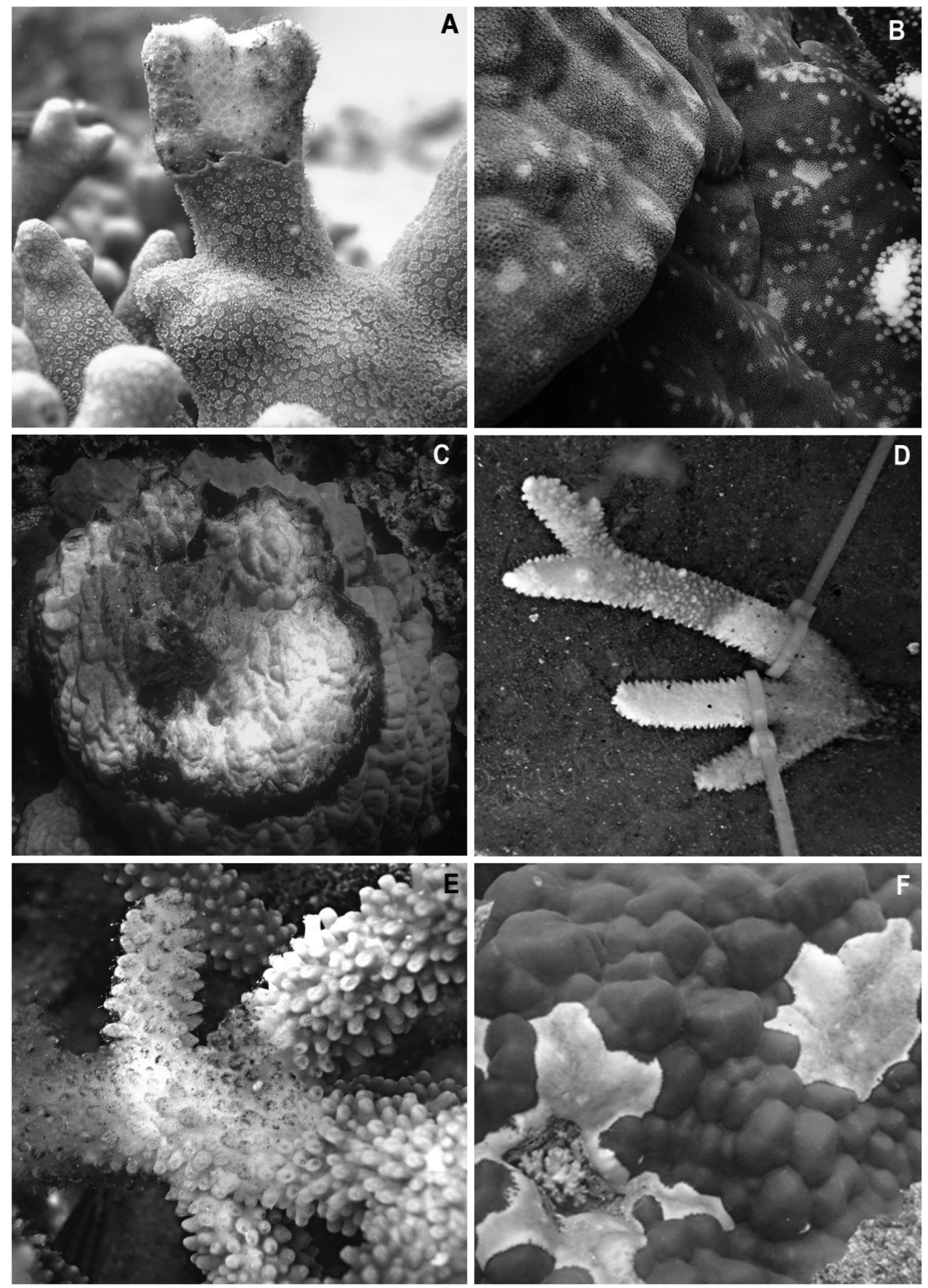

Fig. 2. Six disease states observed affecting Guam corals: (A) white syndrome, (B) ulcerative white spot disease, (C) black band disease, (D) brown band disease, (E) skeletal eroding band, (F) growth anomaly

from crown-of-thorns sea star Acanthaster planci, gastropods (Drupella spp., Coralliophila violacea), and corallivorous fish, patchy bleaching of unknown cause, tissue loss from macroalgal competition (e.g. Sargassum, Corallophila huysmansii; Jompa \& McCook 2003), and silt abrasion and smothering. These influences varied greatly between reefs. Fouha and Ipan reefs, for example, were visibly affected by silt, as they are adjacent to river mouths. Acanthaster outbreaks were ongoing on the reefs of Double Reef and Cocos Lagoon, as shown in the larger percentages of dead standing coral (Fig. 5), and Pago Bay and Anae Island were affected by an Acanthaster outbreak after our surveys were completed. Western Shoals, Achang, and 


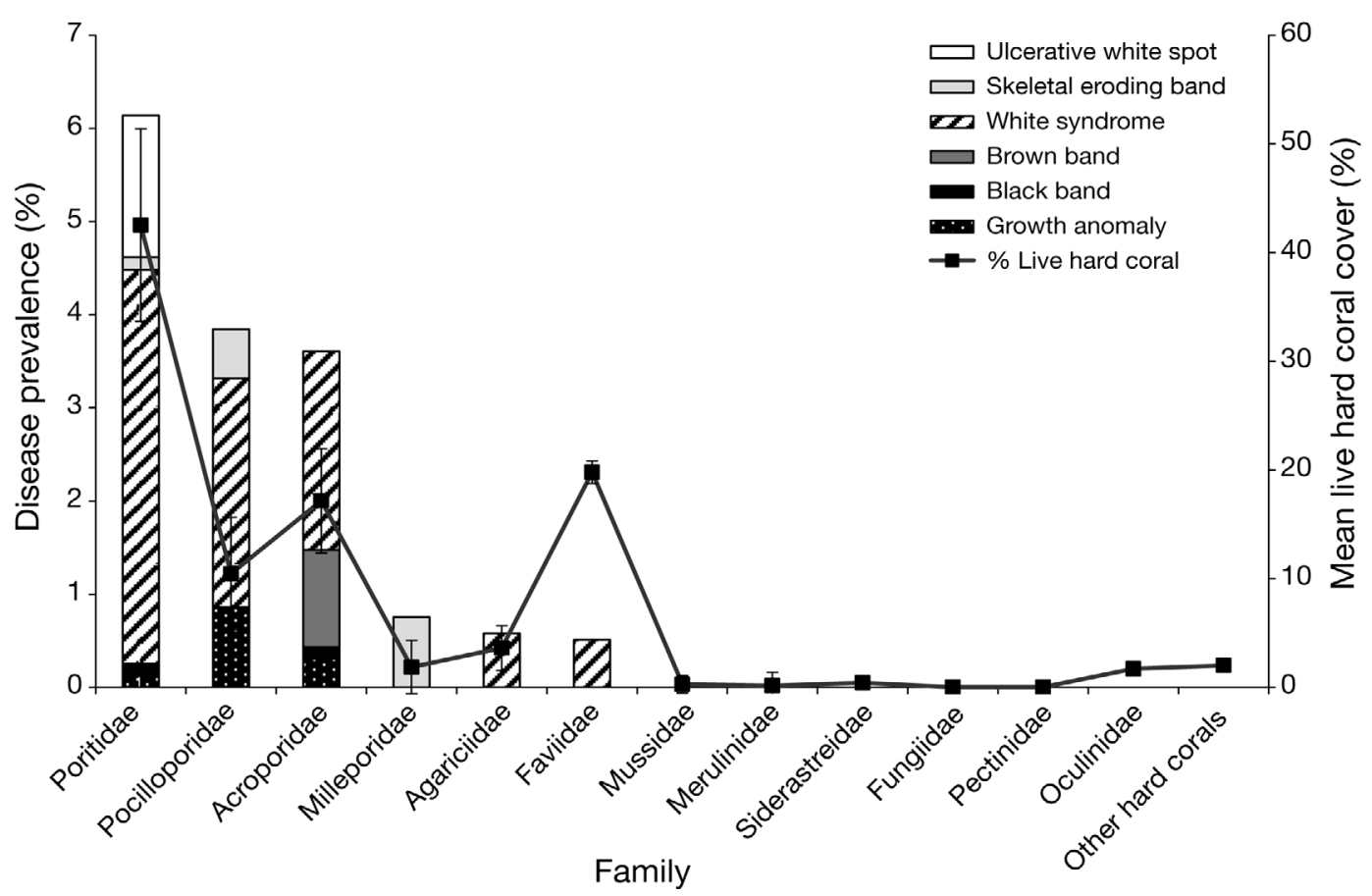

Fig. 3. Mean $( \pm \mathrm{SE})$ abundance of the major hard coral families plotted against disease prevalence, with total prevalence subdivided into the 6 observed diseases ( $\mathrm{n}=15$ sites surveyed)

Shark Pit were affected by seasonal blooms of the brown fleshy macroalga Padina sp. (Fig. 5), and Terpios sp. was abundant on the dominant coral Porites rus along all of our transects at Double Reef.

\section{DISCUSSION}

At present, almost nothing is known regarding disease impacts in the Central Pacific. The present study reports baseline levels of coral disease for Guam, which is the southernmost island in the Northern Mar-

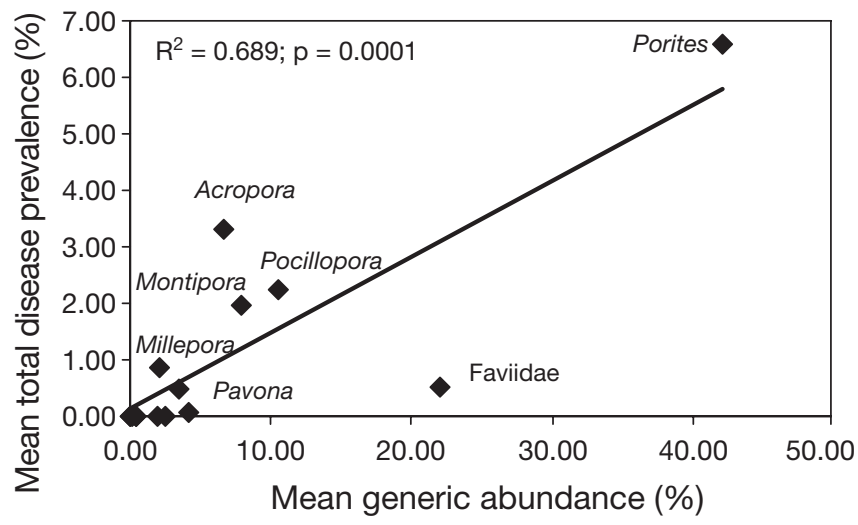

Fig. 4. Linear relationship between abundance of coral taxa, expressed as percent of total live coral cover, and mean $( \pm \mathrm{SE})$ total disease prevalence per genus for 15 sites. Only the 7 most abundant taxa are labeled ianas island chain. Although these surveys were initiated long after Guam reefs showed signs of influences from anthropogenic activities, these data can still serve as an important point of reference for future reef work and a first look at disease effects in a poorly studied region.

Six diseases were identified on Guam, all of which have been documented from other sites within the Indo-Pacific (Willis et al. 2004, Raymundo et al. 2005, Aeby 2006, Kaczmarsky 2006). Our observations of ulcerative white spots on Guam reefs extend the documented geographic range of this disease eastward from the Philippines (Raymundo et al. 2003). Black band and skeletal growth anomalies have both been reported globally, whereas brown band is known only to the Indo-Pacific and chiefly from the Great Barrier Reef (Willis et al. 2004). Recently, a folliculinid ciliate similar to that causing SEB has been found in Caribbean corals (Croquer et al. 2006), suggesting that this disease may also be circumglobal in range. White syndrome is currently hypothesized to be more than 1 disease, and at present, it is not characterized as extensively as the 'white diseases' of the Caribbean (white band types I and II, white plague, white patch; Antonius 1981, Ritchie \& Smith 1998, Patterson et al. 2002, Rogers et al. 2005). It is therefore not known whether any of these Caribbean white diseases may, in fact, be circumglobal in extent. Work is currently underway to characterize this potential suite of diseases. Limited 


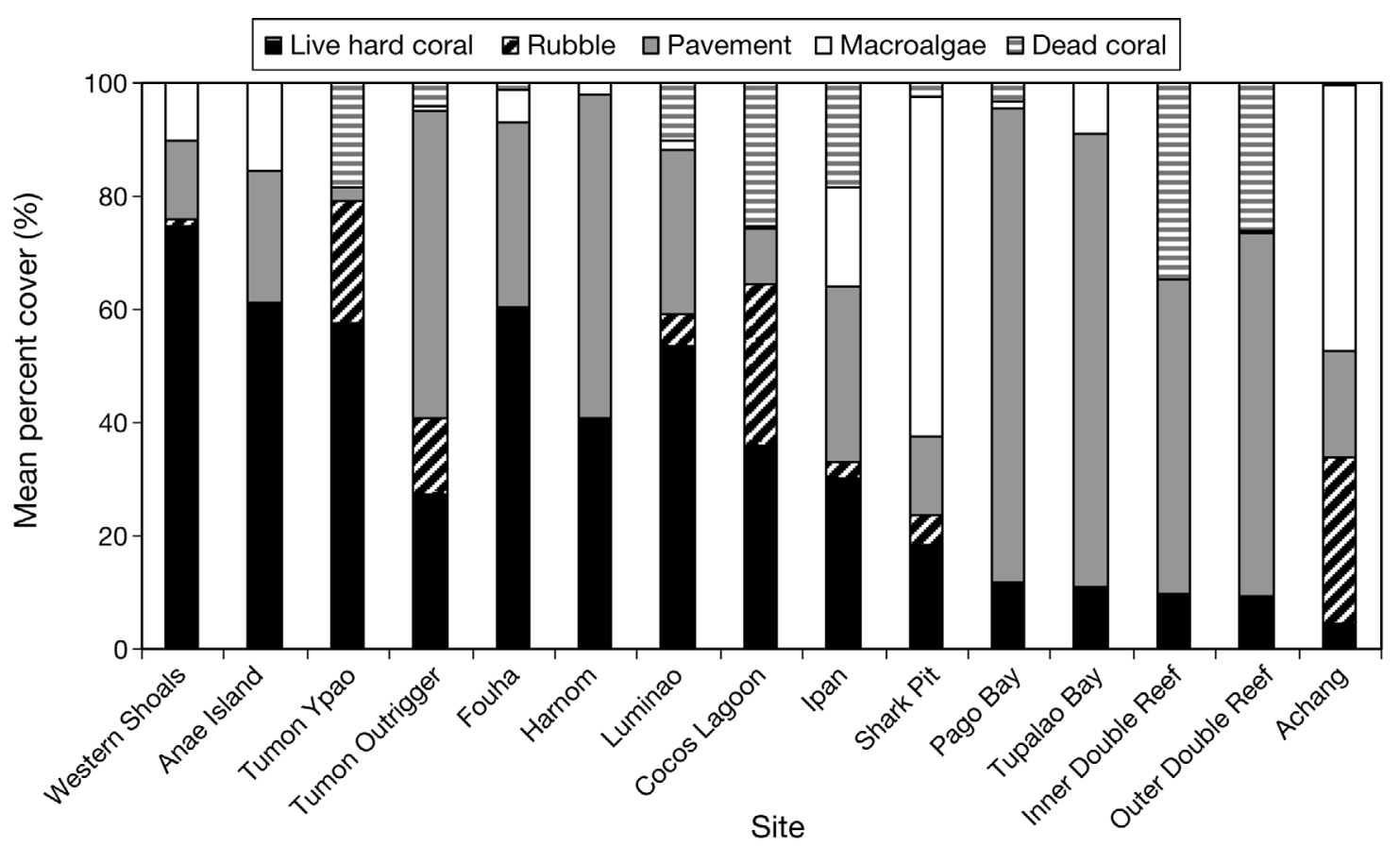

Fig. 5. Relative contribution of major benthic categories of surveyed reefs $(n=15)$ around Guam $\left(n=2\right.$ to 3 transects site ${ }^{-1}$ )

evidence suggests differences in pattern and rate of tissue loss and spread of the disease within colonies between Porites and Acropora, and investigation is also underway to establish a causative agent ( $\mathrm{P}$. Lozada pers. comm.)

Despite the limited spatial extent of Guam's coastal reef area $\left(108 \mathrm{~km}^{2}\right.$; Burdick 2005$)$ and the similarity in coral assemblage species composition across sites, our surveyed reefs varied greatly in disease prevalence. When we tested various factors that we predicted might influence an overall pattern, we found a link with host abundance, i.e. the most common corals were the most affected by disease. However, host density only explained $36 \%$ of between-site variability. Other factors, such as depth, overall coral cover, and proximity to anthropogenic inputs via rivers, did not appear to explain the overall pattern. Our surveys did reveal a number of site-specific sources of stress that may be influencing disease patterns on a local basis. Fouha Bay, for instance, showed a chronic high silt load from land-based erosion carried into the bay by Fouha River. Disease prevalence was low, but mortality and tissue loss due to silt smothering was high and may have masked disease signs. Ipan reef flat, where disease prevalence was the highest, receives discharge from the Togcha River that bisects the flat. The river contains untreated sewage from a nearby housing project and thus, elevated nutrient and bacterial loads. Tumon Bay is the site of concentrated coastal development and recreational activities, and physical damage to corals and nutrient loads are higher here than at other sites. In addition, 2 sites, Harnom and Luminao, had black band disease affecting multiple colonies of a single species even with other known host species present. Outbreaks corresponding to the warm season were consistent with findings of Bruno et al. (2007) and Sato et al. (2009). Considering the diversity of factors influencing various reefs along Guam's coastline, an attempt to determine the drivers of disease prevalence patterns on Guam would necessitate examining each of these types of impacts separately, within replicated sites and quantifying the effects they are having on both water quality and coral health.

Several studies have confirmed a link between host density and infectious disease prevalence (Lafferty 2004, Gerber et al. 2005, Selig et al. 2006, Bruno et al. 2007). Therefore, in Guam and other parts of the IndoPacific, Acropora and Porites would be predicted to be affected more heavily than other species, based on their abundance alone. Significantly, most dominant coral genera appear susceptible to multiple diseases; this reflects a broad host range of several of the diseases currently under study. Porites is both a dominant reef component and a major disease host in Guam, a pattern consistent with findings from other regions (Philippines: Raymundo et al. 2005, Kaczmarsky 2006; Hawaii: Aeby 2006). Acropora is the major reef builder and a dominant disease host of the Great Barrier Reef, Australia (Willis et al. 2004, Selig et al. 2006). Therefore, the capacity for disease to act as a major structur- 
ing force in reef communities is great, but this relationship can also be used to guide management efforts and identify potential disease hotspots. Indeed, major changes in Caribbean coral communities at least partly attributable to disease-induced mortality (Aronson \& Precht 1997, Aronson 2002, Weil 2004) have resulted in focused efforts to protect A. palmata and A. cervicornis, which were placed on the Critically Endangered Species List in 2006 (IUCN 2009).

Current levels of disease indicate that some of Guam's reefs are already at risk of community structural changes linked with chronic high disease prevalence. Initial results of long-term monitoring have shown that disease prevalence at Luminao remains high, though with seasonal fluctuations (L. Raymundo unpubl. data). Given the predicted increase in population and the accompanying development, Guam's coastal water quality is likely to be increasingly impacted, and the baseline information provided by this initial study will be useful in quantifying responses to these changes.

Limited data from 2 sites (Harnom and Luminao) suggest that black band disease displays seasonal changes in prevalence, affecting multiple colonies within a single species even when other known host species are present, and undergoing periodic outbreaks. This link with temperature has recently been verified by Bruno et al. (2007) and Sato et al. (2009) and has been incorporated into the current monitoring program on Guam reefs.

Acknowledgements. We acknowledge the field assistance of P. Rojas Jr. and P. Lozada and logistical support from J. Miller, C. Bassler, and J. Cummings. Funding support was provided by the Guam Coral Reef Initiative and the World Bank-Global Environment Facility Coral Reef Targeted Research Program. We thank 2 anonymous reviewers for their comments, which greatly improved the paper. This paper is Publication No. 625 of the University of Guam Marine Laboratory.

\section{LITERATURE CITED}

Aeby GS (2006) Baseline levels of coral disease in the Northwestern Hawaiian Islands. Atoll Res Bull 543: 471-488

Antonius A (1981) The 'band' diseases in coral reefs. Proc 4th Int Coral Reef Symposium, Manila, p 7-14

Aronson R (2002) Endangered acroporid corals of the Caribbean. Coral Reefs 21:41-42

Aronson RB, Precht WF (1997) Stasis, biological disturbance, and community structure of a Holocene coral reef. Paleobiology 23:326-346

Aronson RB, Precht WF (2001) White-band disease and the changing face of Caribbean coral reefs. Hydrobiologia 460:25-38

Bruno J, Selig E, Casey K, Page C and others (2007) Thermal stress and coral cover as drivers of coral disease outbreaks. PLoS Biol 5:e124
Burdick D (2005) Guam coastal atlas. US Dept Interior, Natl Ocean Atmos Admin, Washington, DC

Cheney DP (1975) Hard tissue tumors of scleractinian corals. Adv Exp Med Biol 64:77-87

Cróquer A, Bastidas C, Lipscomb D (2006) Folliculinid ciliates: a new threat to Caribbean corals? Dis Aquat Org 69:75-78

English S, Wilkinson C, Baker V (1997) Survey manual for tropical marine resources, 2nd edn. Australian Institute of Marine Science, Townsville

> Gerber LR, McCallum HI, Lafferty KD, Sabo JL, Dobson A (2005) Exposing extinction risk analysis to pathogens: Is disease just another form of density dependence? Ecol Appl 15:1402-1414

Gomez ED (1988) Overview of environmental problems in the East Asian Seas region. Ambio 17:166-169

Green E, Bruckner A (2000) The significance of coral disease epizootiology for coral reef conservation. Biol Conserv 96:347-361

Harvell CD, Kim K, Burkholder J, Colwell R and others (1999) Emerging marine diseases - climate links and anthropogenic factors. Science 285:1505-1510

Harvell C, Jordan-Dahlgren E, Merkel S, Rosenberg E and others (2007) Coral disease, environmental drivers, and the balance between coral and microbial associates. Oceanography 20:172-195

Hughes TP (1994) Catastrophes, phase shifts and large-scale degradation of a Caribbean coral reef. Science 265: $1547-1551$

Hughes TP, Baird AH, Bellwood DR, Card M and others (2003) Climate change, human impacts, and the resilience of coral reefs. Science 301:929-933

IUCN (International Union for Conservation of Nature) (2009) IUCN Red List of Threatened Species. Version 2009.1. Available at: www.iucnredlist.org/

> Jompa J, McCook LJ (2003) Coral-algal competition: macroalgae with different properties have different effects on corals. Mar Ecol Prog Ser 258:87-95

Kaczmarsky LT (2006) Coral disease dynamics in the central Philippines. Dis Aquat Org 69:9-21

> Lafferty KD (2004) Fishing for lobsters indirectly increases epidemics in sea urchins. Ecol Appl 14:1566-1573

> Patterson KL, Porter JW, Ritchie KB, Polson SW and others (2002) The etiology of white pox, a lethal disease of the Caribbean elkhorn coral, Acropora palmata. Proc Natl Acad Sci USA 99:8725-8730

> Plucer-Rosario G (1987) The effect of substratum on the growth of Terpios, an encrusting sponge which kills corals. Coral Reefs 5:197-200

> Porter J, Dustan P, Jaap W, Patterson K and others (2001) Patterns of spread of coral disease in the Florida Keys. Hydrobiologia 460:1-14

Porter V, Leberer T, Gawel M, Gutierrez J, Burdick D, Torres V, Lujan E (2005) The state of the coral reefs of Guam. In: Waddell $\mathrm{J}$ (ed) The state of coral reef ecosystems of the United States and Pacific Freely Associated States: 2005 NOAA Tech Memo NOS NCCOS 11. NOAA/NCCOS Center for Coastal Monitoring and Assessment's Biogeography Team, Silver Spring, MD, p 442-487

Raymundo LJH, Harvell CD, Reynolds TL (2003) Porites ulcerative white spot disease: description, prevalence, and host range of a new coral disease affecting Indo-Pacific reefs. Dis Aquat Org 56:95-104

> Raymundo LJ, Rosell KB, Reboton CT, Kaczmarsky L (2005) Coral diseases on Philippine reefs: genus Porites is a dominant host. Dis Aquat Org 64:181-191

Raymundo L, Couch C, Harvell CD (eds) (2008) Coral 
disease handbook: guidelines for assessment, monitoring and management. Currie Communications, Melbourne

Ritchie KB, Smith GW (1998) Type II white band disease. Rev Biol Trop 46 (Suppl 5):199-203

Rogers CS, Sutherland KP, Porter JW (2005) Has white pox disease been affecting Acropora palmata for over 30 years? Coral Reefs 24:194

Sato Y, Bourne D, Willis B (2009) Dynamics of seasonal outbreaks of black band disease in an assemblage of Montipora species in Pelorus Island (Great Barrier Reef, Australia). Proc R Soc Lond B 276:2795-2803

Selig E, Harvell CD, Bruno JF, Willis B, Page CA, Casey KS, Sweatman H (2006) Analyzing the relationship between ocean temperature anomalies and coral disease outbreaks

Editorial responsibility: Kiho Kim, Washington, DC, USA at broad spatial scales. In: Phinney JT, Skirving W, Kleypas J, Hoegh-Guldberg O (eds) Coral reefs and climate change: science and management. American Geophysical Union, Washington, DC, p 111-127

Sutherland KP, Porter JW, Torres C (2004) Disease and immunity in Caribbean and Indo-Pacific zooxanthellate corals. Mar Ecol Prog Ser 266:273-302

Velleman P (1988) DataDesk V. 5.0. Statistics guide. Data Description, Ithaca, NY

Weil E (2004) Coral reef diseases in the wider Caribbean. In: Rosenberg E, Loya Y (eds) Coral health and disease. Springer, Berlin, p 35-68

Willis B, Page C, Dinsdale E (2004) Coral diseases on the Great Barrier Reef. In: Rosenberg E, Loya Y (eds) Coral health and disease. Springer, Berlin, p 69-103

Submitted: January 2, 2009; Accepted: September 1, 2009 Proofs received from author(s): October 13, 2009 